\title{
HISTORIC PRESERVATION IN THE AMERICAN CITY: A NEW YORK CASE STUDY
}

The pressures for destruction of historic buildings are most pronounced in urban areas. Such structures typically do not exhaust the building potential of their location and often are designed for uses different from those of neighboring buildings. As urban concentration increases, the demands for new housing and commercial space become more incessant. These demands are not likely to be ignored by a city government which has needs which could be satisfied by the increased tax revenue which would be generated by new private development. These demands for development sharpen the debate over whether the value of historic preservation outweighs the limitations which it places on urban growth.

New York City has responded to that issue with a comprehensive statutory scheme. The following articles examine the New York legislation and the regulatory structure through which it is implemented. In addition to describing the operation of the statute, the authors comment upon application of the controls by the courts and various planning agencies.

As these articles suggest, the New York program includes policy choices on a number of important issues which must be confronted in any preservation program. In deference to constitutional limitations, it is provided that landmark controls cannot operate to deny the owner of an historic property a reasonable return from his structure. The Landmarks Commission may play an active role in devising a plan which will insure such a return. Another feature of the program which seeks to provide a financial inducement for preservation is the air rights transfer provision which allows a landmark owner to shift development potential from a landmark to nearby lots. In another area, the operation of the Landmarks Commission provides a basis for examining the feasibility of subjecting aesthetic judgments to administrative decision-making. Finally, the program recognizes that the criteria for determining which buildings are of sufficient significance to warrant preservation cannot be legislated with precision, but must be left to an administrative determination made within broad statutory guidelines.

Insufficient time has elapsed since the implementation of the program to permit a final judgment about its effectiveness. The notable feature of this initial effort, however, is the fact that it was undertaken at a time of general public concern for other urban needs. The initial experience outlined in these articles suggests that urban governments need not view historic preservation as incompatible with the demand for urban development. Rather, with appropriate flexibility, planning for historic preservation can be made responsive to the need for continued urban growth.

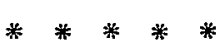




\title{
ZONING AND HISTORIC DISTRICTS IN NEW YORK CITY
}

\author{
JOHN J. LOFLIN*
}

I. Background: Legal Developments. It is now history that the virtually unresticted land use practices which developed in an agrarian society ultimately proved inadequate as the nation's population grew and became concentrated in urban areas. Dissatisfied with the chaotic and uneconomic results of unrestrained decision making as to land use, cities turned to the technique of zoning as a means of control. Zoning, useful in separating the breweries from the cathedrals and residential areas from factories, did nothing to protect buildings of historic and architectural distinction from destruction by developers.

The original preservation efforts relied extensively on private funds for purchase of a threatened property. Even when public money was available for such acquisitions, it was in amounts insufficient to support extensive purchases for preservation. Something less expensive was needed. The first response appeared in Charleston, South Carolina, in I93I, with the establishment of an historic district. ${ }^{1}$ New Orleans and Alexandria, Virginia, soon followed the lead of Charleston.

The initial zoning efforts and subsequent resort to controls for historic preservation have left a history of judicial interpretation. The New York City zoning resolution of $1916,{ }^{2}$ like similar enactments which followed it in other cities, based its claim to constitutionality on the police power. The New York City ordinance was upheld in the state courts in Lincoln Trust Company v. Williams Building Corporation. ${ }^{3}$ In other states, however, the results from the early decisions were mixed. ${ }^{4}$ Faced with conflicting state court decisions, the United States Supreme Court in 1926 considered the federal constitutional objections to a comprehensive zoning ordinance in Village of Euclid v. Ambler Realty Company. ${ }^{5}$ In an opinion authored by Justice Sutherland, the court sustained the enactment as a valid exercise of the police power. By 1930, valid zoning mechanisms existed in all states, and zoning ordinances were in effect in $98 \mathrm{I}$ municipalities.

The judicial reception of preservation devices such as historic districts did not mirror the hostility which had occasionally met early zoning regulations. By the time major preservation schemes came before the courts, a sufficient legal framework for

\footnotetext{
- Member of the firm of Lord, Day \& Lord; former Litigating Assistant Corporation Counsel, New York, New York.

1]. Morrison, Historic Preservation Law I7 (I965) [hereinafter cited as Morrison]; Comment, The Police Power, Eminent Domain, and the Preservation of Historic Property, 63 CoLum. L. REv. 708, 7r3I4 (I963).

2 Morrison 2; G. SMith, The Law and Practice of Zoning 2-3 (i937).

${ }^{3} 229$ N.Y. 3I3, I28 N.E. 209 (I920).

'R. ANderson, AMERican Law of Zoning § 2.08 (Ig68).

${ }^{5} 272$ U.S. 359 (I926).

${ }^{\circ}$ C. Haar, land Use Planning i65 (1959).
} 
validation had been laid in litigation involving refined zoning questions. Significant among these prior developments were decisions dealing with governmental authority to control billboards. As the ordinances which attempted this control touched directly upon matters of aesthetics, the judiciary was forced to grapple with the outer limits of the police power. One early court saw aesthetic considerations as "a matter of luxury and indulgence rather than of necessity ...."T The general trend, fortunately, has been otherwise. A number of states accept aesthetic considerations alone as a basis for zoning controls, but most still look for other grounds as well if the ordinance is to be sustained. ${ }^{8}$

With the background provided by these decisions, historic district enactments have fared well in court. Building on a foundation of health, safety, and welfare, the courts have readily added aesthetic and economic factors to sustain restrictions designed to preserve local districts. Increased property values, gains from tourist business, and a recognition of historic values have been cited to sustain a variety of regulatory schemes. The historic districts in New Orleans, Sante Fe, and Greenwich Village in New York City, among others, have been challenged and sustained. ${ }^{?}$

The popularity of the historic district concept has increased in recent years. District legislation now appears in areas as diverse as San Antonio, Texas; Salem, Massachusetts; Natchez, Mississippi; and Maui County, Hawaii. Some states, such as Massachusetts, have set up historic districts by direct legislation, but more commonly, state statutes authorize localities to enact ordinances for the preservation of their own areas. Morrison describes some fifty-one local ordinances designating historic districts. ${ }^{10}$

2. The Landmarks Preservation Law of New York City. While New York City enacted the first zoning ordinance in this country, it was not until 1956 that the state legislature passed enabling legislation for the designation of landmarks and historic districts. Nine years later, in 1965 , the city responded with its Landmarks Preservation Law. ${ }^{11}$ The enactment provided for a Landmarks Commission with authority to designate structures as landmarks and areas as historic districts. The operation of the Commission is considered in detail in the following paper by J. Lee Rankin. It is important to note here that the Commission has authority to designate an area as an historic district if it contains improvements which

(a) have a special character or special historical or aesthetic interest or value; and

(b) represent one or moxe periods or styles or architecture typical of one or more eras in the history of the city; and

${ }^{7}$ City of Passaic v. Paterson Bill Posting, Advertising \& Sign Painting Co., 72 N.J.L. 285, 287, 62 A. 267,268 (I905).

${ }^{8}$ See Masotti \& Selfon, Aesthetic Zoning and the Police Povver, 46 J. Urban Law 773 (1969).

${ }^{-}$City of New Orleans v. Pergament, I98 La. 852, 5 So. 2 d 129 (194r); City of Santa Fe v. GambleSkogmo, Inc., 73 N.M. 410, 389 P.2d I3 (1964); Ragone v. Landmarks Preservation Commission, N.Y.L.J., July 15, 1969, at 2, col. 6 (Sup. Ct.), aff'd 33 App. Div. 2d 1105, 308 N.Y.S.2d 293 (1970).

${ }^{10}$ MORRISON I2-18, I29-86 (1965).

${ }^{11}$ N.Y.C. AdMin. CODE ch. 8-A (Supp. 1970). 
(c) cause such area, by reason of such factors, to constitute a distinct section of the city ....12

The Commission made extensive studies, with the aid of its professional staff, of buildings and areas throughout the City. Those buildings, sites, or areas that had landmark potential became the object of special investigation by the staff. If a building or area seemed to be qualified for designation, notice of a public hearing to consider designation was sent to the owners affected. The owners and other interested persons-historical societies and professional architectural organizations, for example-presented their views at the hearing, and after further consideration, a designation could be issued. This in turn was subject to the approval of the Board of Estimate, a body of elective public officials which has in fact approved, with one exception, all of the buildings and areas designated by the Commission. A property owner aggrieved by the designation of his property as a landmark or inclusion of his property within an historic district also has recourse to the state courts under the provisions of article $7^{8}$ of the New York Civil Practice Law and Rules. The litigation has not been extensive, but each attempt to declare the law unconstitutional has failed. Since its creation, the Landmarks Commission has designated 360 buildings or sites as landmarks and eighteen areas as historic districts.

Once an historic district has been designated, it becomes unlawful for any person to construct, reconstruct, alter, or demolish any improvement within the parcel without first obtaining approval of the Commission. In considering applications for construction within a district, the Commission must determine whether the proposed work would change, destroy, or affect any architectural feature of the improvement in question and the effect of the proposed work on neighboring buildings in the district. In its evaluation of the proposal, the Commission must consider "the factors of aesthetics, historical and architectural values and significance, architectural style, design, arrangement, texture, material and color."13

3. The Districts. The several areas designated as historic districts in New York mirror the diverse history of the city. They range in size from the ten former carriage houses of Sniffen Court to the Brooklyn Heights and Greenwich Village districts which include hundreds of buildings of great variety. All but two of the districts benefit from complete residential zoning. Greenwich Village, the most diverse historic district in the city, has both residential and commercial zoning within its boundaries. Some impression of the variety of buildings within this district can be gained from the Commission's designation report:

The principal architectural styles of Greenwich Village, represented by the largest number of buildings in the District, are the Federal, Greek Revival, Italianate, French Second Empire, Nea-Greco and Queen Anne. The streets offer a delightful mixture of these styles, while within each style can be found visual harmony here, achieved through the uniform rows of builder-constructed town houses, the pre-

\footnotetext{
${ }^{23}$ Id. $\$ 207-\mathrm{I} . \mathrm{o}(\mathrm{h})(\mathrm{r})$.

${ }^{13}$ Id. $\$ 207-6.0(\mathrm{~b})(\mathrm{2})$.
} 
dominantly low building heights, and the use of materials such as brick and brownstone, the symmetrical placement of windows and other qualities which have, in this neighborhood, the authentic flavor of the periods represented..$^{14}$

One district, Hunters Point, located on the East River in Long Island City in the Borough of Queens, is an island of town houses in a neighborhood of railroad yards and manufacturing facilities. This area was first settled early in the seventeenth century but remained farmland until home development began in the I850's. Despite the intrusion of the Long Island Railroad terminal in $\mathrm{x} 86 \mathrm{I}$ and the development of factories, the homes in a small area survived intact to become a valuable and still useful reminder of the City's past.

A number of New York's districts, prior to designation, were threatened by destruction or decay. The situation in Brooklyn Heights is illustrative. This excellent residential area cross the East River from lower Manhattan was threatened both by developers of new but stylistically undistinguished buildings and by deterioration of some of the older buildings which had been converted into rooming houses. The concept of an historic district had great appeal to those who wanted to preserve the unique qualities of this area. The testimony at the Commission's public hearing showed that:

Of the 1,284 buildings fronting on streets within the proposed Historic District, at least 684 were built before the Civil War and at least Io 8 before the turn of the century. There are 60 Federal, 405 Greek Revival, 47 Gothic Revival, and 20r Anglo-Italianate buildings as well as 216 buildings in eclectic and miscellaneous styles, not to mention 6I early carriage-houses grouped largely along unspoiled mews. ${ }^{15}$

The designation of the Brooklyn Heights historic district was approved; the area has stabilized and the value of the homes there has substantially increased. When sound aesthetic judgment is joined with clear economic benefit, the intrusion of governmental controls designed to preserve the area seems benign indeed to those who are regulated.

\section{OPERATION AND INTERPRETATION OF THE NEW YORK CITY LANDMARKS PRESERVATION LAW}

\section{J. LeE RANEIN*}

I. Operation of the Law. The Landmarks Preservation Law was passed under the New York State Historic Preservation Enabling Act of 1956, which granted mu-

\footnotetext{
14 I New York City Landmarks Preservation Commission, Greenwich Village Historic District Designation Report, i5 (I969).

${ }^{15}$ New York City Landmarks Preservation Commission, Brooklyn Heights Historic District Designation Report 2 (I965).
}

- Corporation Counsel of the City of New York. 
nicipalities the authority to provide for the protection and preservation of buildings and places of "special historical or aesthetic interest or value" and for the control of the use and appearance of neighboring property. The landmarks law was preceded by a statement of legislative purpose, listing many of the reasons usually given for historic preservation. ${ }^{1}$ The list began with the preservation of districts and sites of cultural, social, economic, historic, and architectural value. It went on to include the protection of property values in the districts, the encouragement of community pride in the accomplishments of the past, the promotion of tourism, and the general strengthening of the economy of the city. It concluded with the purpose of promoting the use of historic districts for the education, pleasure, and welfare of the city's residents. The act is distinct, however, from most others in its broad definition of the subjects it seeks to preserve-landmarks, landmark sites, historic districts, exterior architectural features, and others.

Under the landnarks act, an historic district is one which contains improvements which have a special character or special historic or aesthetic value. It must represent one or more periods or styles of architecture typical of one or more periods in the city's history. It also has to be designated an historic district under the provisions of the act. A landmark is defined similarly, but in addition, it must be at least thirty years old. The act provides for the Landmarks Commission to take the initiative in designating a landmark or district, and it is required to hold a hearing before it makes such a designation. But the Board of Estimate has the power to exercise a veto over the designation within ninety days on the ground that it will interfere with any development plans.

After a designation is recorded in the City Register, the Commission has a number of powers. With respect to any improvement in an historic district or landmark site, it may impose limitations or conditions which are more restricted than those prescribed by other provisions of law which may be applicable. However, any alteration, reconstruction, demolition, or construction on a landmark site or in a district requires a Commission certificate. Projects which are aided by the city are excepted, but even those are subject to prior report to the Commission. Commission approval is not require to proceed with a city-aided project.

The landmarks act follows other similar enactments by regulating only the exterior of a property. The Commission is required to pass on proposed work "in creating, changing, destroying or affecting the exterior architectural features of the improvement upon which such work is to be done ...." The Commission cannot pass upon bulk and height, space, location of industry or trade activities, or density of the population-powers usually lying with zoning authorities. Should the Commission determine that a proposal would alter the exterior of the improvement, the applicant may seek a certificate of appropriateness, or file an alternative applica-

\footnotetext{
${ }^{1}$ N.Y.C. ADMrn. Cone ch. 8-A (Supp. I970). The discussion in this section of the article pertains only to the provisions of the Act; therefore, further citations to the Act are not included.
} 
tion in the first instance, seeking a decision that the proposal will not affect the exterior. Failing in that, he may then request a certificate of appropriateness. A public hearing is required on each application for a certificate of appropriateness. The Commission must act within ninety days of the filing of the application and set forth the reasons for its decisions. A denial of one application does not preclude a new application or the renewal of a prior one.

In the event an owner establishes that he is unable to earn a reasonable return on his landmark property, he is protected. If the Commission denies the certificate, the burden is then upon it to devise a plan, which may include but is not limited to a grant of partial or complete tax exemption, remission of taxes, and authorization of alteration, construction, or reconstruction consistent with the Commission's standards. The act limits the time for supplying such a plan to sixty days. If the plan includes tax abatement or remission, it must be approved by the Board of Estimate. The owner thereafter has the right to accept or reject the plan. If ho rejects it, or if a plan is not forthcoming within sixty days, or if the plan is not approved after a hearing, the Commission must then within ten days send the mayor a recommendation that the city acquire a specific protective interest in the property. The act recognizes that the interest to be acquired may range from an easement to a fee title, as may be required in the judgment of the Commission. Finally, if the city takes no action, the Commission must then grant the owner a notice to proceed with the originally rejected plan.

Tax-exempt structures designated as landmarks are subject to a standard which is in several important respects different from that applicable to structures which are fully taxed. The owner of tax-exempt property is not governed by the provisions under which other owners may shift the burden of planning to the Commission upon a showing that a reasonable return could not be secured were Commission regulations followed. Rather, to gain relief from the regulations regarding demolition and alteration, the owner of a tax-exempt structure must meet four requirements: (I) he must have entered previously into an agreement to sell the fee, or he must have entered into at least a twenty-year lease, providing that the contract is contingent upon his procuring a certificate of appropriateness or a notice to proceed; (2) the property must not be capable of earning a reasonable return without the tax exemption; (3) the structure sought to be altered must not be adequate for the purpose to which it had been devoted, unless the charitable owner is no longer pursuing those purposes; (4) the prospective owner must intend to demolish, alter, or reconstruct the structure promptly. Upon meeting the four conditions, the Commission must within I8o days find an alternate purchaser or tenant who will agree to buy or lease without a certificate of appropriateness. Such a buyer or lessee must accept an interest identical to that which had been tentatively accepted, or reasonably equivalent in terms and conditions.

2. Judicial Interpretation of the Act. The leading case under the act involved 
Sailors' Snug Harbor, a charitable institution caring for retired mariners. ${ }^{2}$ The Harbor sought an order from the court vacating a determination by the Commission that certain of its buildings on Staten Island are landmarks. The buildings are outstanding examples of Greek Revival and Anglo-Italianate style, dating from 1830 to I88o. The Harbor wished to demolish the buildings because it considered them no longer adequate for use as dormitories for the seamen. The Harbor claimed that the buildings were obsolete since they were not fireproof, had no elevators, and did not provide the space required. It planned to replace the landmark buildings with a combined high-rise dormitory and infirmary. Thus, the buildings were objected to not only as useless and expensive to maintain, but also because they would block the view from the proposed new buildings.

The thrust of the Harbor's argument was that the distinction in the act between taxpaying and tax-exempt owners constituted unreasonable discrimination, in violation of the fourteenth amendment and the New York State Constitution. The trial court declined to rule on that question, but it did grant an order vacating the designation, holding that the burden upon the landowner was disproportionate to the benefit the public could derive from the designation, and thus, was an unlawful taking of property without just compensation. The court noted that Staten Island and Sailors' Snug Harbor are seldom visited by tourists and concluded that the burden of maintaining useless property in view of the provisions in the act against neglect was unreasonable. The court viewed the action as "spot zoning," and since the properties were not in an historic district, the Harbor could not obtain the benefits of any increased value to compensate for the limitation.

The Appellate Division unanimously reversed and remanded the action, holding that the issue of whether aesthetic and cultural benefit to the community is an adequate basis for exercise of the police power had long been resolved in favor of aesthetics. The remaining issue then became whether the Commission's designation constituted a taking of the property without just compensation. The court agreed that the act was designed to avoid this, but the act did not set forth the criteria for ascertaining the extent of the burden on the owner in cases in which a charitable owner did not wish to sell. The court also recognized that in some cases the Commission might provide relief, but that in others not covered by the statute, the court was not restricted from doing so. It stated that in charitable cases the guideline as to what constituted an undue burden would be whether the maintenance of a landmark either physically or financially prevented or seriously interfered with the charitable purpose. It also suggested that the relevant considerations on retrial would be whether the property could be converted to a useful purpose, the cost of such conversion, the extent of the interference with the use of the property, and the cost of maintenance. The Sailors' Snug Harbor case has not been retried. The city

\footnotetext{
${ }^{3}$ 'Trustees of the Sailors' Snug Harbor v. Platt, 53 Misc. $2 d$ 933, 280 N.Y.S.2d 75 (Sup. Ct. 1967), rev'd, 29 App. Div. 2d 376, 288 N.Y.S.2d $3{ }^{2} 4$ (I968).
} 
has since decided to acquire the designated buildings and is in the process of negotiations to that end.

The principles established in the Sailors Snug Harbor case are of major importance. Of primary interest is the court's recognition of the right of a city to designate landmarks based on aesthetic and cultural considerations. The holding was essentially based on prior decisions in New York establishing the right of the state to regulate the use of land based on aesthetic considerations in the field of zoning. ${ }^{3}$ This case is also another example of the extension of traditional concepts of public health and safety. ${ }^{4}$ Several state courts have cited Berman v. Parker ${ }^{5}$ in support of this concept, but it is doubtful whether the case justifies such reliance. Nevertheless, the trend toward upholding such regulations on aesthetic grounds seems to be growing despite the fact that courts still rely on economic factors in support of their decisions. $^{6}$

Another challenge to the act by a charitable institution came in Lutheran Church in America v. City of New York.7 A brownstone located next to the Morgan Library on Madison Avenue had been designated by the Commission. The threestory building was once occupied by two families distinguished in the history of the city. The landmark structure had been purchased to provide a headquarters for the Lutheran Church in America but had since become too small for such use. The Church wanted to tear down the designated landmark and erect a new structure on the site.

It was claimed that the city, by its designation of the building, sought by administrative fiat to divert to its own use funds entrusted to the Lutheran Church for its religious mission. It was also asserted that by the designation the value of the structure had been cut in half. The Church also contended that the Commission's action constituted a denial of the free exercise of religion. The Church's inability to replace the Church House with a new structure, adequate to its needs, interfered directly in the conduct of its religious affairs by preventing the consolidation of its

\footnotetext{
${ }^{3}$ People v. Stover, r2 N.Y.2d 462, I9I N.E.2d 272, 240 N.Y.S.2d 734 (r963).

'City of New Orleans v. Levy, 223 La. 14, 64 So. $2 \mathrm{~d} 798$ (1953); City of New Orleans v. Impastato, I98 La. 206, 3 So. 2d 559 (I94I); City of New Orleans v. Pergament, I98 La. 852, 5 So. $2 d$ I29 (x94I); Opinion of the Justices, 333 Mass. 783, 128 N.E.2d 563 (1955); City of Santa Fe v. Gamble-Skogmo, Inc., 73 N.M. 4xo, 389 P.2d 13 ( 1964 ). In a zoning case the New York Court of Appeals did not rely solely on aesthetic considerations in upholding an absolute bar of billboards. It did recognize that the aesthetic consideration was realistically the primary object of zoning law. Cromwell v. Ferrier, rg N.Y.2d 263, 269, 225 N.E.2d 749, 752-53, 279 N.Y.S.2d 22, 26-27 (1967).

' 348 U.S. 26 (1954). The portion of the opinion often cited is Mr. Justice Douglas' statement of support for aesthetic considerations: "It is within the power of the legislature to determine that the community should be beautiful as well as healthy, spacious as well as clean, well balanced as well as carefully patrolled .... . If those who govern the District of Columbia decide that the Nation's Capital should be beautiful as well as sanitary, there is nothing in the Fifth Amendment that stands in the way." It is doubtful whether the right to designate historic districts or landmarks upon aesthetic considerations can be supported by this dictum. The case involved a redevelopment plan to eliminate and prevent substandard housing conditions in a large area of the District of Columbia. This plan was within the broad scope of the police power, and thus, was not upheld on the basis of aesthetic considerations.

See Comment, Legal Methods of Historic Preservation, I9 Buff. L. REv. 6II, 6I7 (1970).

${ }^{7}$ No. 4I575/66 (Sup. Ct., Nov. 21, I966), rev'd, 27 App. Div. 2d 237, 278 N.Y.S.2d I (1967).
} 
offices on the site of the Church House. It claimed that in so doing the desire of the Church and that of the other Lutheran bodies to bring their offices together in one building was frustrated.

The trial court held that Civil Practice Law and Rules, section 2I7, which prescribes a four-month statute of limitations for article $7^{8}$ proceedings, was applicable to this action for a declaratory judgment and that the Church's action, commenced approximately eight months after the designation of the Lutheran Church House as a landmark, was time-barred. Such a proceeding would have been based on the Church's contention that the action was unconstitutional as a taking of Church property with neither due process of law nor just compensation.

The Appellate Division reversed and remanded the case for a new trial. ${ }^{8}$ It held that although an article 78 action could have been brought before the statute of limitations had run, the declaratory judgment action would still lie since the Church was questioning not merely the designation but also the constitutionality of the act. Upon retrial, the trial court held that the designation was not authorized by the act (even though the Appellate Division had said that this was not an issue in the case). ${ }^{9}$ The court said, "[a]ssuming the constitutionality of such statutes, the court finds that the designation of the structure at issue as a landmark is not justified within the scope, the purposes and powers of the Landmark Preservation Commission."10 It therefore concluded that the structure was not a landmark within any reasonable interpretation of the statute, and the case is now pending before the Appellate Division. ${ }^{11}$

The concept that the courts were free to reverse the Commission by a reexamination of the evidence, even when the issue was properly before the courts, was rejected in Manhattan Club v. Landmarks Preservation Commission. ${ }^{12}$ It held that the function of the courts was merely to determine whether there was substantial evidence to support the designation and relied upon the principle that, "the court may not substitute its judgment for that of the administrative agency . . . ."13 The Manhattan Club case was one of the early cases under the New York City Landmarks Preservation Law. In it the court recognized and approved the principle that architectural, historical, and aesthetic values are a valid subject of legislative concern, and that reasonable legislation designed to promote these values is a valid exercise of the police power. Unfortunately, and despite the Commission's success in court, it was unable to find a buyer for the property who would leave it intact, and finally, the Club was demolished. This case is dramatic proof that the effectiveness of the act is ultimately determined by the financial commitment the city makes

\footnotetext{
${ }^{8} 27$ App. Div. 2d 237, 278 N.Y.S.2d I (I967).

N.Y.L.J., Feb. 25, I97r, at I8, col. 5 .

${ }^{10} \mathrm{Id}$.

${ }^{12}$ No. 41575/66 (App. Div., Sup. Ct., filed Apr. I4, r971).

${ }^{13} 5 \mathrm{r}$ Misc. $2 \mathrm{~d} 556,273$ N.Y.S.2d (Sup. Ct. I966).

${ }^{13} \mathrm{Id}$. at $559 ; 273$ N.Y.S.2d at 502.
} 
to support the preservation of architectural, historical, and aesthetic values precious to the maintenance of its traditions.

Historic district regulations under the act have also been tested. In Ragone $v$. Landmarks Preservation Commission, ${ }^{14}$ it was argued that the designation of a portion of Greenwich Village as an historic district was beyond the authority of the Commission because improper notice was given of a requisite public hearing. The court held that the notice requirements of the statute had been complied with, and it did not pass on the designation status since that was still pending. In a second proceeding by Ragone, the Commission defended on the ground that the prior action was res judicata, and a new argument that personal notice was required was rejected.

There are a number of important issues yet to be resolved concerning the New York landmarks law and its application. Of prime importance are such questions as: How much interference can be allowed before the issue of a taking without just compensation arises? Are constitutional questions raised in that portion of the act which requires owners of tax-exempt property to meet a potentially more stringent standard than those owning taxed property before they are relieved of their obligation to secure a Commission certificate for alterations? Is the fact that a taxexempt owner may forego his exemption and thereafter receive the same rights under the act as any taxpaying owner a protection against claims of unconstitutional invasion of rights? What procedural requirements are insufficient, if any ? $^{15}$

$* * * * *$

\section{AIR RIGHTS TRANSFERS IN NEW YORK CITY}

\section{Norman Marcus*}

I. Background. Historic buildings situated in high land value areas present a unique problem to their owners and to the municipalities which seek to preserve them. Often, these buildings are located in areas in which a new office building on the site of the landmark would bring the land owner a significantly greater financial return than is realized from the historic building. On the other hand, the aesthetic and cultural values of the community call for the preservation of local landmarks. Structural disfigurement or total demolition destroys forever the irreplaceable representatives of the life styles of the past. In any attempt to solve the problem that this divergence of goals creates, a balance must be sought between preservation and an owner's right to financially rewarding use of his property.

\footnotetext{
14 N.Y.L.J., July 15, 1969, at 2, col. 6, affd 33 App. Div. 2d I105, 308 N.Y.S.2d 293 (x970).

${ }^{16}$ See Comment, Landmark Preservation Latus: Compensation for Temporary Taking, 35 U. CHI. L. REV. 362 (1968).
}

- Counsel, Department of City Planning, City of New York. 
The development potential of a lot is defined by zoning controls. New York's Zoning Resolution allows a certain height, bulk, and density for structures on each lot proportionate to the size of the lot and appropriate to its location. The concept which is used to control the amount of building on a lot is the floor area ratio (FAR). The floor area ratio precludes the sandwiching of extra floors within the height limit. ${ }^{1}$ Coupled with room size minimums, it makes an effective population control. ${ }^{2}$ As a rule, landmarks tend to be small structures. Hence when they are located in the central areas of the City, they are substantially below the maximum permissible floor areas. Current FAR controls in Manhattan, for example, allow the construction of buildings which are considerably larger than the extant landmarks of an earlier era. There is no incentive for an owner of an underdeveloped lot to do anything but demolish and rebuild according to the allowable FAR maximum. If the landmark is preserved, a theoretical "surplus" of unused floor area is created. To retain the desirable underdevelopment of a landmark site, it is necessary to find another location which can use its development potential. There will be a market for the transfer of air rights from landmark sites when there is a substantial demand for office or residential space and vacant lots large enough to support buildings of greater FAR than is usually allowable on those lots. ${ }^{3}$

Traditionally, the New York City zoning laws have permitted the transfer of air rights between contiguous building sites held in common ownership. A landmark's unbuilt development potential could thus be deployed on a contiguous site within the same zoning lot. A zoning lot is a tract of land, on one block, which is to be developed as a unit under the control of a single owner. This requisite control is not restricted to fee ownership. The current Zoning Resolution defines the ownership interest necessary for classification as a zoning lot as "including a lease of not less than fifty years duration with an option to renew said lease so as to provide a total lease of not less than 75 years duration." In accepting a longterm lease as lot control comparable to fee ownership, the city looked at the useful life of the new structure as measured by the standard mortgage terms. The seventyfive year lease interest was regarded as ample in view of these considerations. ${ }^{5}$

The simplest case of transferable air rights would consist of a group of contiguous underdeveloped and undeveloped sites in single fee ownership. Fee ownership of an

\footnotetext{
${ }^{2}$ Without the FAR concept, a builder could comply with height limitations and still avoid density control by lowering ceiling heights and reducing storage, insulation, or lobby areas.

${ }^{3}$ Broadway Laguna Vallejo Association v. Board of Permit Appeals, 59 Cal. Rptr. 146, 427 P.2d 81o (Ig67).

${ }^{3}$ If, on the other hand, a municipality's floor area control is so generous to development as to be nonexistent, the essential hunger for floor area that is necessary to support a landmark air rights transfer will be lacking.

'New YoRr, N.Y., ZoNing Resolution \$ I2-Io (I96x).

${ }^{5}$ Apparently not anticipated were situations created by a default under the lease after the leased parcel had been stripped of its air rights potential by a new structure on a contiguous portion of the new zoning lot. A recent case raised the fundamental question of the automatic operation of the transfer principle contemplated by the Zoning Resolution where the parties to the lease evidenced no intention to achieve that result. Newport Associates Inc. v. Solow, 36 App. Div. 2d 5I9, 3I7 N.Y.S.2d 7I5 (I97I).
} 
assemblage of contiguous lots gives an owner close to absolute control over his total parcel and permits arrangement of bulk within the overall lot at the owner's option. ${ }^{\circ}$ When some of the lots have already used a portion of their FAR building allotment and others are vacant, additional construction on any part of the composite will be permitted if the proposed building together with the existing older buildings does not exhaust the total FAR of the zoning lot. ${ }^{7}$

The air rights transfer which occurs between contiguous lots merged into a new and larger zoning lot presents a clearly allowable case of transfer. The more difficult situation is the one where no merger is possible. All of the sites contiguous to the landmark may be improved with structures not susceptible to redevelopment. Or there may be a series of adjacent landmark structures. Lot mergers do not apply to situations which require the transfer of development rights across several lots or even across adjacent blocks. New York departed from the traditional canon in I968 when it adopted a Zoning Resolution which permits the transfer of a landmark's air rights to a non-contiguous lot. ${ }^{8}$ Under this Resolution, the City Planning Commission may permit air rights to be transferred from a landmark to an adjacent lot. According to the definition of adjacent which the Resolution adopts, the air rights may be transferred to a contiguous site or to one across a street or street intersection. The maximum FAR overage permitted on the transferee site is twenty per cent. To arrive at the amount of transferable floor area, the floor area of the existing landmark building is subtracted from the floor area that would be allowable if the spot were vacant. Any floor area transferred is irrevocably substracted from the development potential of the landmark site.

To effect such a transfer an application must be made to the City Planning Commission. This must include a site plan of the landmark and the transferee lot and a program delineating a plan for maintenance of the landmark. The procedure in New York requires the Landmarks Preservation Commission to report to the Planning Commission on the proposed transfer, giving its reaction to the site plan for the landmark lot and the transferee lot and the program for continuing maintenance of the landmark. Recommendations by the Planning Commission to the builder concerning modifications in design of the proposed building, to insure compatibility with the landmark, are also in order.

2. Application of the Air Rights Transfer Provisions. Approximately one year after the 1968 provision was adopted, a private developer leased from the Penn-Central Railroad the air rights of Grand Central Terminal, which has a FAR of 2 in a district whose maximum FAR is I8. He planned to exhaust the FAR of the zoning lot by suspending an office tower over the terminal. Because this proposal would have an exterior effect on the landmark, the Landmarks Commission ruled that the tower

\footnotetext{
${ }^{6} \mathrm{He}$ has absolute control except for mandatory height and setback requirements which are not relevant to the issue.

7 The Department of Buildings enforces zoning and approves composite development.

${ }^{8}$ New YoRK, N.Y., Zoning REsolution $\$ \$ 74-79$, 791, 792, and 793 (r968).
} 
could not be built as a matter of right. ${ }^{9}$ Before going into effect, such a proposal has to be subjected to the Commission's procedures which are designed to protect the landmark.

In I 969 an amendment to the Ig68 air rights transfer provision was made. The amendment significantly increases the distance across which air rights can be transferred in maximum density commercial areas. While the Ig68 version permits transfer across $a$ street, the $I g 69$ enlargement allows a linking of tracts over more than one street. Adjacent sites are defined to include "a lot ... . which is across a street and opposite to another lot or lots which except for the intervention of streets or street intersections form a series extending to the lot occupied by the landmark building. All lots shall be in the same ownership." This language permitted transfer to any lot in a chain of common ownership as long as the first link was across the street from the landmark zoning lot. The Ig68 provision did not provide the flexibility needed in the Terminal case. Lots which would have been eligible under the existing law, those immediately contiguous to the Terminal and those across the street from it, were precluded from serving as transferee lots because they were already sufficiently improved.

In response to the difficulties presented by the Terminal case, the Ig68 provision was further relaxed to permit transfer of all of the unused development potential to a single site in a high density commercial district without regard to the twenty per cent overage limit. This decision was, in part, a reaction to the financially troubled owner's eagerness to quickly convert the development rights into revenue producing office space. If the twenty per cent overage limit were observed, many different transferee sites would be required to exhaust the excessive underdeveloped FAR potential of the Grand Central Terminal lot. According to real estate experts, a widespread redevelopment of the area sufficient to consume the development potential of the lot was unlikely. The abandonment of the overage restriction was also justified by the prevalence of non-complying buildings in the area. It was felt that one more extra-large building would be relatively innocuous. Furthermore, the requirement of a chain of common ownership offered the opportunity to condition development rights transfer permission on circulation improvements in the area, which would have ameliorated the impact of an overly large new building on the transferee site. Currently, however, the Grand Central project is dormant due to the bankruptcy of the Penn-Central Railroad and the overall decline in the market for office space in New York City.

After the Grand Central episode, another air rights transfer situation arose. The City reached an interesting result with respect to the requirement of a program for the continuing maintenance of the landmark. The Ig68 Resolution does not spell out the program necessary for continuing maintenance. Rather, the maintenance requirement is left unstructured in order to allow tailoring of the maintenance

\footnotetext{
${ }^{0} \mathrm{New}$ York, N.Y., Local Law No. $46 \S 207-5.0$, Apr. I9, I965.
} 
program to the specific needs of the particular landmark. A landmark may be a thoroughly remunerative proposition, either by virtue of tourist fees or profitable commercial or residential use. In estimating the necessary inclusion in the total transfer price of additional cost for maintenance, these factors are highly relevant to the City. Clearly, the price of the transfer should not be made to include the full maintenance of the landmark if such a requirement would inhibit the transaction and thus the preservation of the landmark. The City's treatment of the requirement in the case of Igth Century Amster Yard, a privately owned series of residences and minor commercial structures with an interior garden on a through lot, shows how this principle operates in a practical setting. ${ }^{10}$ The owner of this landmark proposed to sell a portion of his unused development rights to an adjacent parcel on Third Avenue where an office building was going to be constructed. An arrangement was worked out between the owners which provided for a \$roo,00o trust fund, the income of which was to be applied to maintenance of Amster Yard. Of the five trustees of the fund, two are nominees of the landmark owner, one is a representative of the local Turtle Bay community, one is the chairman of the Landmarks Preservation Commission, ex officio, and one is associated with a leading architectural firm. Although not a party to the contract, the City of New York took an active role in shaping its substance to insure preservation of the landmark. Understandably, the purchase price for the air rights was partly a function of the amount of money extracted for preservation purposes. The trust fund was a welcome "first" under the air rights transfer provision. ${ }^{11}$ Unfortunately, the A.mster Yard arrangement has yet to be put into opeartion due to the lull in the office building market in New York.

Another, more ambitious air rights transfer is envisioned under a different provision of the New York City Zoning Resolution, section 74-74, dealing with large scale commercial developments in urban renewal areas. South Street Seaport, a collection of buildings from the original Fulton Street Fish Market days falls under this section. While various groups organized preservation efforts, land speculators quietly bought adjacent sites and even succeeded in acquiring some of the historic buildings themselves. A plan was needed to allow the South Street buildings' air rights to be transferred to a commercial redevelopment plot somewhere else in the area.

The entire area was made subject to an Urban Renewal Plan containing a preservation area and a redevelopment area. ${ }^{12} \mathrm{~A}$ redevelopment site perimeter was established within which development rights could be shifted. Under the renewal plan, all the floor area potential not exhausted by the old structures on the South

\footnotetext{
${ }^{10}$ New York City Planning Commission Rep. CP-21236 (I970).

11 The City in its consideration of the matter spent much of its time on the issue of compatibility of the new office structure with the landmark. In this connection, the office developer accepted certain design modifications including dark red brick facing, mansarded bay windows, and a through block arcade giving access to and harmonizing with the smaller landmark structures.

${ }^{12}$ New York City Planning Commission ReP. CP-20533, CP-21222 (rg69).
} 
Street Seaport zoning lots which were zoned for the moderately high commercial bulk of FAR I2 could be shifted for construction onto a parcel of no particular historic value. Since it was a small block, the zoning lot chosen to receive this infusion of development rights had to be relieved of normal tower coverage and setback requirements to enable it to digest the full development potential of the seaport sites. In order to permit such a transfer, the Planning Commission had to add section $74-742$ (c)(2) to the findings previously contained under section 74-742 as follows:

(a) That such distribution of floor area and location of buildings will result in better site planning and better architectural relationships of buildings and open spaces to adjacent streets and surrounding development, and will thus benefit both the neighborhood and the City as a whole.

(b) That such distribution of floor area and location of buildings will not unduly increase the bulk of buildings in any one block or unduly obstruct access of light and air, to the detriment of the occupants or users of buildings in the block or nearby blocks or of people using the public streets.

(c) That where a tower is permitted to occupy more than $4^{\circ}$ per cent of the lot area of the zoning lot on which it is located, at least 50 per cent of the entire site will be developed either as

(I) plaza or as open area designed for public use and enjoyment contiguous to a plaza and at no greater elevation than the plaza to which it is contiguous, or

(2) in the case of an urban renewal project, as landmark and historic buildings plus public spaces, public amenities and public uses that are related to them.

The new finding permitted the Commission to waive a light and air requirement on the zoning lot if there was adequate assurance of at least equivalent light and air in the vicinity because of the preservation of the small scale landmark and historic buildings. Landmark and historic buildings which were to be preserved in the Seaport were analogized to plaza or open area by the Planning Commission which saw them as comparable amenities for public enjoyment. The Commission agreed to the transfer on the condition that it resulted in the preservation of these buildings. But, as in the transactions described above which relied on the demand for office construction to support landmark or historic preservation, this proposal has not yet germinated due to the slow office market in Lower Manhattan.

Currently, the Landmarks Preservation Commission and the City Planning Commission are wrestling with the problem of a great many landmarks in close proximity on Manhattan's upper east side. The existing provisions for air rights transfer are not adequate to make available enough transferee lots to receive the development potential of this area's landmarks. As a result, widespread transferability of landmark air rights has been urged. There emerged, however, a competition for the privilege of receiving the air rights in the area.

The Planning Commission unsuccessfully attempted to preserve the scale of four 
and five story mid-block brownstones on Manhattan's Upper East Side by permitting their development rights potential to be transferred within the same block to avenue redevelopment sites. The Commission's proposal sought to increase the number of dwelling units in new buildings on the avenue and to preclude any redevelopment of existing mid-blocks. ${ }^{13}$ A twenty per cent maximum FAR overage for avenue sites was proposed. Neighborhood groups from Manhattan's Upper East Side defeated the proposal. They fought it primarily to avoid relocation. They predicted that the proposal would generate the formation of assemblages of sites and result in ultimate elimination of ethnic and economic diversity from the old rent-controlled structures. This controversy has underscored the likelihood that a broadened air rights transfer provision, if applied to old rent-controlled housing, would cause relocation and social exclusivity. Such a technique applied to residential areas assumes redevelopment in the form of private luxury apartments in which the occupants of demolished rent-controlled housing will find no home.

3. Conclusion. Traditional zoning ordinances do not permit transfer of unused air rights to non-contiguous lots. Such conveyances are regarded as contrary to the prevailing notions about the need for uniformity of controls in a given area. It is felt that the essential interrelationship of zoning density controls to street width, transit access, school seats, and other objects of planning concern could not survive indiscriminate transferability of unused air rights between widely spaced parcels. The unit of development control chosen by the City was the zoning lot. Had the City chosen a different unit of control as its basis-perhaps a block basis, or a square mile basis-there would have been no bias against wider area transferability of development potential. A block by block control could achieve density objectives as successfully as a lot by lot approach.

The experience of the unsuccessful attempt to introduce air rights transfer techniques in the residential market of Upper Manhattan raises the conceptual problem of over how many blocks the benefit of a preserved landmarks FAR excess should be spread. If the unrestricted transfer of air rights over a large area cannot be justified, reasonable restrictions can be developed. Transferor and transferee lots could be limited to similar use, height, and bulk zoning districts within a maximum radius of each other. The radius should be something wider than the current rigid requirement of contiguous or opposite lot which governs outside of maximum commercial density districts. As in the Grand Central case, pragmatism will probably contribute more to the answer than theory.

The transfer of air rights zoning technique clearly depends on the existence of a healthy private development market. Such a market both poses a threat to the landmark structure which underutilizes its land, and provides its salvation if the zoning rules permit. This zoning technique is intriguing, but air rights transfers may never be fully exploited for landmark perservation purposes unless such an objective

\footnotetext{
${ }^{13}$ New York City Planning Commission Rep. CP-21420 (not adopted).
} 
is a priority goal of the city's well considered plan. Landmarks have to make their case for priority on a competitive basis along with other worthy social objectives.

*****

\section{AESTHETICS IN HISTORIC DISTRICTS}

\section{Harmon H. Goldstone*}

It was a lawyer, the late Albert J. Bard, who first introduced the word aesthetic into the laws of the State of New York. His amendment to the General City Law, adopted on April 2, 1956, has since been widely cited as the Bard Law. ${ }^{1}$ The word aesthetic had, until the Bard Law was enacted, been carefully avoided in proper legislative circles. This attitude is quite understandable for the word opens a Pandora's box of ill-defined, if not essentially undefinable, concepts which are capable of stirring people to strong passions. From Socrates to Santayana some very ugly arguments have taken place over the question of what is beautiful and what is not. Even the meaning of the word has never been resolved to everyone's satisfaction.

Yet, eleven independent-minded individuals, as the officially appointed members of New York City's Landmarks Preservation Commission, have the responsibility of making aesthetic judgments every day. These aesthetic judgments are made in connection with the Commission's power to grant or deny requests to construct, reconstruct, alter, or demolish a landmark or portion of an historic district. Their authority for doing so stems directly from the New York City's Landmarks Preseravtion Law of 1965 which lists the consideration of aesthetic values and significance as one of the factors gaverning the determination of such a request. ${ }^{2}$ This mandate and the declaration of public policy in the preamble $e^{3}$ to the statute involve the Landmarks Preservation Commission in making not only aesthetic judgments, but also in considering cultural, historical, social, economic, political, architectural, utilitarian, recreational, promotional, and educational questions, as well

* F.A.I.A., A.N.A.; Chairman, Landmarks Preservation Commission; member of Goldstone, Dearborn \& Hinz, Architects, New York City.

${ }^{1}$ N.Y. GeN. City Law $\$ 20(25-a)$ (McKinney I968), as amended N.Y. Gen. Munic. Law $\$ 96-a$ (McKinney Supp. I970).

2 N.Y.C. AdMun. CODE ch. 8-A, $\$ 207-6.0($ b) (2) (Supp. 197o).

3 "b. It is hereby declared as a matter of public policy that the protection, enhancement, perpetuation and use of improvements of special character or special historical or aesthetic interest or value is a public necessity and is required in the interest of the health, prosperity, safety and welfare of the people. The purpose of this chapter is to (a) effect and accomplish the protection, enhancement and perpetuation of such improvements and of districts which represent or reflect elements of the city's cultural, social, economic, political and architectural history; (b) safeguard the city's historic, aesthetic and cultural heritage, as embodied and reflected in such improvements and districts; (c) stabilize and improve property values in such districts; (d) foster civic pride in the beauty and noble accomplishments of the past; (e) protect and enhance the city's attractions to tourists and visitors and the support and stimulus to business and industry thereby provided; $(f)$ strengthen the economy of the city; and (g) promote the use of historic districts and landmarks for the education, pleasure and welfare of the people of the city." Id. \$205-I.0. 
as in the cultivation of civic pride and general welfare. It is not surprising that at times this multiplicity of responsibilities makes decisions on individual cases difficultparticularly difficult when they hinge primarily on so subjective a criterion as an aesthetic judgment. The following suggestions are presented as guidelines which may be helpful in making such decisions.

The criteria that are appropriate to the design of an entirely new building within one of New York City's historic districts are quite different from those that are appropriate to the replacing of a missing part of an existing old building. Within an historic district there is also a third situation in which, from one point of view, the criteria applicable to the district as a whole seem appropriate while, from another point of view, the situation should be treated as if an isolated building were being restored. Each of these three problems will be considered in turn.

I. New Buildings in Old Districts. The City of New York has thus far designated as historic districts eighteen areas containing over 6,000 properties. The popularity of this part of the landmarks preservation program has exceeded all expectations. More people than anyone had ever imagined really enjoy living and working in neighborhoods that are characterized by the harmonious qualities of good urban design and by a sense of continuity with the past. The joint effort to preserve these qualities has raised community morale, and the designation of historic districts has, in fact, proven to be a surprisingly potent force for social stabilization.

It is important, however, to understand the difference between New York City's historic districts and the various "museum towns" that have been preserved, restored, and reconstructed around the country. The museum towns can equally well be justified, but for quite different reasons. Williamsburg freezes a moment of historythe climax of British colonial culture in Virginia. Plymouth Plantation shows how the earliest New England settlers lived, dressed, and worked. Cooperstown demonstrates the forthright qualities of nineteenth century rural crafts. Richmondtown shows how a country town, a county seat, grew and developed for over two centuries. These history lessons-in three dimensions-are valuable and deservedly popular. Since they are, in the full sense of the word, "museums," a curatorial approach is quite properly applied not only to every detail of each building but also to every aspect of the surroundings. The streets, the street lighting, the gardens, the wallseven the costumes of the guides and the horse drawn carriages-must all be as exactly consistent with the period represented as it is possible to achieve. It is quite appropriate, therefore, in these museum towns to insist that, insofar as possible, every aspect of the work be carried out by means of the same handcraft techniques that were originally used. Although these demonstrations are fascinating and instructive, they are not, and are not intended to be, integral and vital parts of a dynamic metropolis in which twentieth century people live and earn a living.

If a New York City historic district is not a museum piece in the sense of a Williamsburg or a Plymouth Plantation, then what, exactly, are the qualities that set 
it apart from its surroundings? What is there about it that is worth preserving? And how can these worthwhile qualities be preserved?

The statutory definition of a New York City historic district requires that "special character or special historical or aesthetic interest . . . cause such area ... to constitute a distinct section of the city," provides that it may "represent one or more periods or styles of architecture typical of one or more eras in the history of the city . ..."5 In fact, most of the historic districts contain a wide variety of styles. Despite this heterogeneity, there are attributes which unify these distinct sections.

A high, general level of architectural quality in the majority of their buildings is a first criterion, but of equal significance is the fact that despite a mixture of styles, an historic district conveys an agreeable feeling of harmony that is in strong contrast with the surrounding areas of the city. This sense of harmony does not depend upon uniformity of style; rather, it is based on the qualities of good urban design. That these have developed naturally, spontaneously, and even accidentally, in certain isolated areas of the city is our good fortune. Now that these areas have been identified and officially designated, it is the responsibility of the Landmarks Preservation Commission to insure that future growth and change within an historic district be guided along the lines that gave it, in the first place, the qualities we appreciate. These qualities are, in descending order of importance, mass, color, scale, and style.

In specific terms the most important factor to be maintained is uniformity of the roof line and the setback line; next, compatibility of color, texture, and rype of materials; third, the scale of the openings; and, finally, the details of a particular architectural style or fashion. It is a sensitive variation of individual designs within the limits of these criteria that gives our historic districts so much of their appeal. It is particularly important to note that, insofar as the attractive character of the street scene is concerned, adherence to the details of a particular architecturab style is the least important factor. In fact, when there is complete conformity in each of the four criteria a deadly monotony can result.

When an entirely new structure is proposed to be built on an existing empty lot in an historic district, the significant criterion that should control its design is compatibility with its neighbors in mass, color, and scale. Every age in history has produced an architecture expressive of its economics, aspirations, techniques, materials, and aesthetics. It is the harmonious juxtaposition of these evolutionary changes that gives our historic districts so much of their interest.

A pressing question concerns the desirability of demanding that new buildings conform to the architecture of the period represented in the district. There are those who would discriminate against introduction of the architectual expression of our own era. Proponents of this view bear the burden of showing the appropriate

\footnotetext{
II. $\$ 207-\mathrm{I} .0(\mathrm{~h})(\mathrm{I})(\mathrm{a})-(\mathrm{c})$.

${ }^{5} I d . \$ 207-\mathrm{r} .0(\mathrm{~h})(\mathrm{r})(\mathrm{b})$.
} 
historical cutoff point. The difficulty encountered in this task provides an answer to their own arguments about the inappropriateness of expressions. An actual example makes the point. Brooklyn Heights began to emerge in its present form after the opening of the Fulton Street Ferry in I8I4. In a recent census, the district contained 60 Federal style houses, 405 Greek Revival houses, 201 Anglo-Italianate houses, and 216 in miscellaneous, eclectic styles dating from after the Civil War. If a Landmarks Preservation Commission had been established around 1830 and if it had supported the point of view that nothing could be added to an historic district that did not follow the style of what was already there, then ninety-three per cent of what most of us at present enjoy would not exist today. If such a commission had not been established until I860, we would still miss almost half of the best buildings that now survive on the Heights.

Growth and change must occur in New York City's historic districts if they are to remain vital parts of a dynamic organism. When a new building is proposed for an empty lot which may have existed at the time the district was designated or which may, for whatever reason, have become subsequently available, then the aesthetic criteria appropriate to its design are exactly the same as those that unconsciously guided its predecessors through their various periods and styles-compatibility of mass, color, and scale with its surroundings. The new building should also be as good an expression of the architecture of our own period as the best of its predecessors were of theirs.

This standard admits of one exception. In the few historic districts that are completely homogeneous in style, new buildings-in order to preserve the entirely uniform character of their surroundings-should also conform in style. These are, however, rare and exceptional situations.

2. New Parts for Old Buildings. A different question is presented by a suggested replacement of a damaged or missing part of an old building in an historic district or the correction of inappropriate changes which earlier owners may have made without appreciation of the architectural qualities of their building. It is the responsibility of the Landmarks Preservation Commission not only to insist on the retention of every good building that has survived in an historic district but also to encourage its appropriate restoration. The protection of such architecture is inherent in the very fact of the district's designation.

If the building in question is entirely of one period and style and has come to the Commission complete, except for the missing part, then to replace that part with anything which did not closely match the original would impair the integrity of the original design. It is a rare occasion when the part can be replaced with something that was made at the same time and in the same manner as the original. If such a part is not obtainable, a hand-crafted imitation is preferable to a machinemade copy, particularly when it will be located at eye level. If the hand skills are no longer available, or if the owner cannot afford to pay for them, a good machine- 
made reproduction is better than either omitting the part or inserting something obviously different in style from the rest of the facade.

The argument is sometimes made that any new work added to an old building should be so immediately distinguishable that no one will be deceived by what is "original" and what is not. This is the archaeologist's attitude, and he is quite justified when he is reconstructing some great monument of antiquity. $\mathrm{He}$ is anxious, on the one hand, to recreate the original overall appearance of the structure and, on the other, not to pretend that his contemporary restoration is part of the original work. To apply this sort of scholarly conscientiousness to the replacing of a missing brownstone baluster or a section of a simple Greek Revival cornice misses the point of preservation of such works. Even the best of buildings in any of New York City's historic districts are simply good examples of honest workmanship in a variety of once-popular styles. The names of a few of the architects who designed them are known, but hundreds of the buildings that give the historic districts their appreciated quality were erected by anonymous builders who worked from stock plans. Their value is their overall effect. To insist, for the sake of archaeological purity, in distinguishing new work from old could destroy the very values sought to be preserved.

3. Mixed Situations. While clear and valid distinctions can thus be made between the criteria appropriate for the restoration of a single building in a single style and for the erection of an entirely new building on an empty lot within an historic district, there remain two types of mixed situations for which appropriate aesthetic criteria are more difficult to fix. To restore a building of mixed styles or to add an entirely new wing, with new functions, onto an old building is a more subtle and complex problem. In such cases, the Commission must also consider the relative visual "weights" of one part to another, their historic associations, and the visual relationship of the parts in question to their surroundings. An attempt may be made to carry over the color and some of the materials and characteristic details from one part of a structure to another, as in Edgar Tafel's Ig60 addition to Joseph C. Well's Gothic Revival First Presbyterian Church on the corner of Fifth Avenue and r2th Street in New York City. Or only the gross scale of the adjoining row houses may be carried over-in contrasting materials and with starkly contrasting detail-as in James Stewart Polschek Associates' remarkably interesting new headquarters for the New York State Bar Association in Albany, New York. ${ }^{6}$

An actual example of the second sort of mixed situation recently came before the Commission for decision. The problem concerned the design of an entirely

\footnotetext{
${ }^{\circ}$ For illustrations of these and similar examples, see Goldstone, The Marriage of New Buildings with Old, Historic Preservation, Jan.-Mar. I971, at I9-23.

${ }^{7}$ See New York City Landmarks Preservation Commission IPC-70239 Certificate of Appropriateness \#186, 18 West IIth Street, Greenwich Village Historic District, Block 574, Lot 35, Manhattan, May I8, I97I, with attached reports in favor of and in opposition to the granting of the Certificate. Since this case was before the Commission at the same time that the present article on aesthetics in historic districts was being written, much of the material in the favorable report, with which a majority of the Commission concurred, is similar to the argument which is given here in more general terms.
} 
new building on an empty lot in the middle of a row of similar houses. The question raised was whether a row of houses, built at the same time, should be considered as a single architectural composition or simply as a series of individual buildings that happen to bear a closer resemblance one to another than to the others around them. Is the problem of filling a gap in such a row the same as restoring a missing part to an individual building, or is it, rather, like erecting a new building on any other vacant lot within an historic district? There seems to be no single, simple, and universally applicable answer. It depends on the nature of the row and its surroundings. It is necessary to determine whether the row was originally conceived as a unified composition, as the Royal Crescent in Bath; or whether it fills an entire block front as does the row on Washington Square North (with one intrustion) between Fifth Avenue and University Place; or whether it defines a distinctive geometric form, as does the so-called "Renwick Triangle" in the St. Marks Historic District. It may be that a row merely starts where the original developer's property began and stops where his money ran out. Other considerations are the present condition of the other houses of the row and the nature of their surroundings. In short, the Commission seeks to identify the elements that give a particular section of an historic district its qualities and then asks whether a specific proposal to fill a gap in the row would enhance or harm these qualities.

If this discussion of aesthetics in historic districts seems to have proposed more questions than answers, it is because the problem is a complex and subtle one. The Commission is frequently urged to supply a simple set of guidelines so that the owner of a property in an historic district would merely have to ascertain the style of his building in order to learn exactly how to carry out appropriate repairs and replacements. While there would be no particular difficulty in preparing an illustrated collection of typical and "correct" details for every one of the many styles that occur in New York City's several historic districts, the compendium would have limited applicability. Such an encyclopedia would provide no answers to the broader questions that have been raised here. It would supply no clue as to whether in a specific case it is more appropriate to be archaeologically pure or to provide a visually acceptable imitation, what style should be followed in buildings of mixed character, how to add a compatible new wing onto an old building, or when a row is an architectural entity in itself or merely a fairly uniform stretch in an otherwise heterogeneous neighborhood. A mere catalogue of period details would give no consideration to the fundamental questions of to what a given set of aesthetic criteria are being applied and why they should be so applied.

It was to decide such matters as these that the New York City Landmarks Preservation Commission was intentionally set up to be as widely representative as possible. It is not a committee of historians, or of designers, or of architectural historians, or of professional politicians, or of popular community leaders. It consists of eleven members, serving three year overlapping terms, and the Commission must at all times contain three architects, one city planner or landscape architect, one realtor, one historian specializing in New York City history, and concomitantly, one 
resident from each of the City's five boroughs. By prudent tradition it has also included one or two lawyers, preferably with experience in municipal government, and several laymen with no specialized qualifications other than their concern for the City's good. The drafters of the Landmarks Preservation Law felt that such a Commission of devoted and experienced non-specialists would be best equipped to reach just decisions on the complex, aestheic problems it must resolve. 